УДК 556:556.314:550.47

\title{
ВЛИЯНИЕ БИОГЕОХИМИЧЕСКОЙ ОБСТАНОВКИ ВОДОСБОРНОГО БАССЕЙНА ОЗЕРА ТЕЛЕЦКОЕ (СЕВЕРО-ВОСТОЧНЫЙ АЛТАЙ) НА СОДЕРЖАНИЕ ГЛАВНЫХ ИОНОВ И Fе В ВОДАХ ЕГО ПРИТОКОВ
}

\author{
Пузанов Александр Васильевич', \\ puzanov@iwep.ru
}

\section{Бабошкина Светлана Вадимовна 1 , svetlana@iwep.ru, arsenida@rambler.ru}

Рождественская Тамара Анатольевна 1 , rtamara@iwep.ru

\section{Балыкин Сергей Николаевич 1 , balykins@rambler.ru}

1 Институт Водных и экологических проблем СО РАН, Россия, 656038, г. Барнаул, ул. Молодежная, 1.

2 Институт Водных и экологических проблем СО РАН, Россия, г. Новосибирск, Морской пр., 2.

\author{
Балыкин Дмитрий Николаевич1 \\ balykindn@yandex.ru
}

Салтыков Алексей Владимирович1, saltykov@iwep.ru

Трошкова Ирина Александровна ${ }^{1}$, egorka_iren@mail.ru

\section{Двуреченская Серафима Яковлевна², serafima_dv@mail.ru}

Актуальность исследования обусловлена необходимостью расширять и уелублять представления о формировании и функционировании крупных пресноводных объектов, химический состав которых тесно связан с особенностями биогеохимических процессов и почвенного покрова водосборной площади и с характером антропогенной нагрузки на окружающую среду водосборных бассейнов. Однако механизмы этих взаимодействий в условиях горных территорий пока еще недостаточно полно изучены.

Цель: установить связь содержания главных компонентов солевого состава вод притоков Телецкого озера и особенностей их химической денудации с биогеохимической обстановкой водосборных бассейнов.

Методы. Пробы воды из притоков озера Телецкое отбирали в чистую полиэтиленовую посуду в устьевой части рек, в пери-

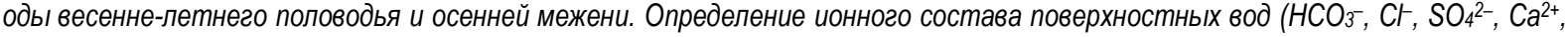
$\mathrm{Mg}^{2+} \mathrm{Na}^{+}$u $\mathrm{K}^{+}$) проводили по стандартным методикам, с титриметрическим или спектрофотометрическим окончанием. $\mathrm{Na}^{+}$ и $\mathrm{K}^{+}$в 2018 и 2019 ге. определяли методом атомно-эмиссионной спектрометрии на приборе IRIS Advantage Thermo Jarrell Ash corp. (1999). Содержание $\mathrm{Fe} \mathrm{в} \mathrm{водах} \mathrm{и} \mathrm{водных} \mathrm{вытяжках} \mathrm{из} \mathrm{почв} \mathrm{определяли} \mathrm{методом} \mathrm{атомно-абсорбиионной} \mathrm{спектрометрии} \mathrm{c}$ использованием электротермической атомизации на приборе SOLAAR M-6.

Результаты. Установлено, что воды притоков озера Телецкое отличаются невысоким уровнем общей минерализации, от 18 до 159 мг/л. Показано, что сезонная динамика главных ионов определяется биогеохимическими процессами, происходящими на водосборе. Выявлено, что воды восточных и западных притоков, дренирующие различные по геологической и ландшафтннй структуре, а также по степени рекреационной нагрузки берега, отличаются как по содержанию, так и по соотношению главных ионов. Так, в ионный состав вод восточных притоков, берущих свое начало на гранитном хребте Корбу,

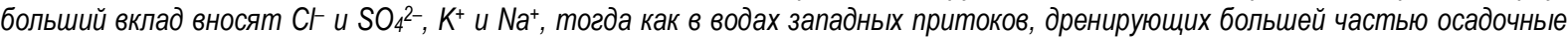
отложения, выражено доминирование гидрокарбонатов и кальция. Показано влияние биогеохимической обстановки водосборных бассейнов на содержание и соотношение железа в воде и водной вытяжке почв. Установлено, что больщинство притоков озера Телецкое несут воды гидрокарбонатно-магниево-кальциевого типа. Рассчитаны показатели ионного стока трех различных по величине притоков озера, оценена химическая денудация в их водосборных бассейнах. За один год с водами самого крупного притока - рекой Чульшшман - в озеро поступает 364 тыс. т основных растворимых солей. С 1 км² водосборного бассейна р. Чульшман выносится 21 m солей (это меньше, чем с водосборов более мелких притоков), из них 12,8 $m$ - гидрокарбонатов, 1,4 $m$ - хлоридов, 1,6 m - сульфратов, 4,5 m - кальция, 0,4 m - магния.

Ключевые слова:

Озеро Телецкое, притоки, водосбор, главные ионы, железо, биогеохимическая обстановка, ионный сток.

\section{Введение}

Все водоемы и водотоки являются составной частью географического ландшафта, поэтому химический состав их вод определяется биогеохимическими процессами на водосборе [1-5], а также зависит от вида и степени антропогенного прессинга на речные бассейны [6-9]. Однако механизмы процессов взаимодействия системы «водосбор-вода» в бассейнах горных рек пока еще недостаточно полно изучены.
Основную часть стока растворенных веществ составляет ионный сток (95\%). Трансформация стока главных ионов в водах рек является основным индикатором природы выветривания горных пород в бассейнах $[8,9]$, предикторами для расчетов режима экспорта влаги и растворенных веществ с водосборов [10]. По величине ионного стока реки можно проанализировать изменчивость химической денудации $[2,11]$, которая в бассейнах рек горных территорий пока еще недостаточно полно изучена. 
Цель работы - изучить сезонную и годовую динамику содержания главных компонентов солевого состава вод притоков Телецкого озера и установить связь их химического состава с биогеохимическими особенностями водосборных бассейнов.

\section{Объекты исследования}

Озеро Телецкое - крупнейший водоем Алтая, одно из самых глубоких и красивых озер России, располагается среди высоких горных хребтов на высоте 434 м над ур. м. С 1998 г. озеро Телецкое является объектом Всемирного природного наследия ЮНЕСКО.

Озеро имеет руслообразную форму и представляет собой глубокий ледниковый трог, заполненный 40 км$^{3}$ чистой пресной холодной воды $[12,13]$. Озеро питают более 70 рек, но основную массу воды приносит с южной стороны р. Чулышман - около $5 \mathrm{kм}^{3}$ в год $[12,14]$. Сток воды через верхний створ р. Бии составляет $7 \mathrm{kм}^{3}$ в год [12].

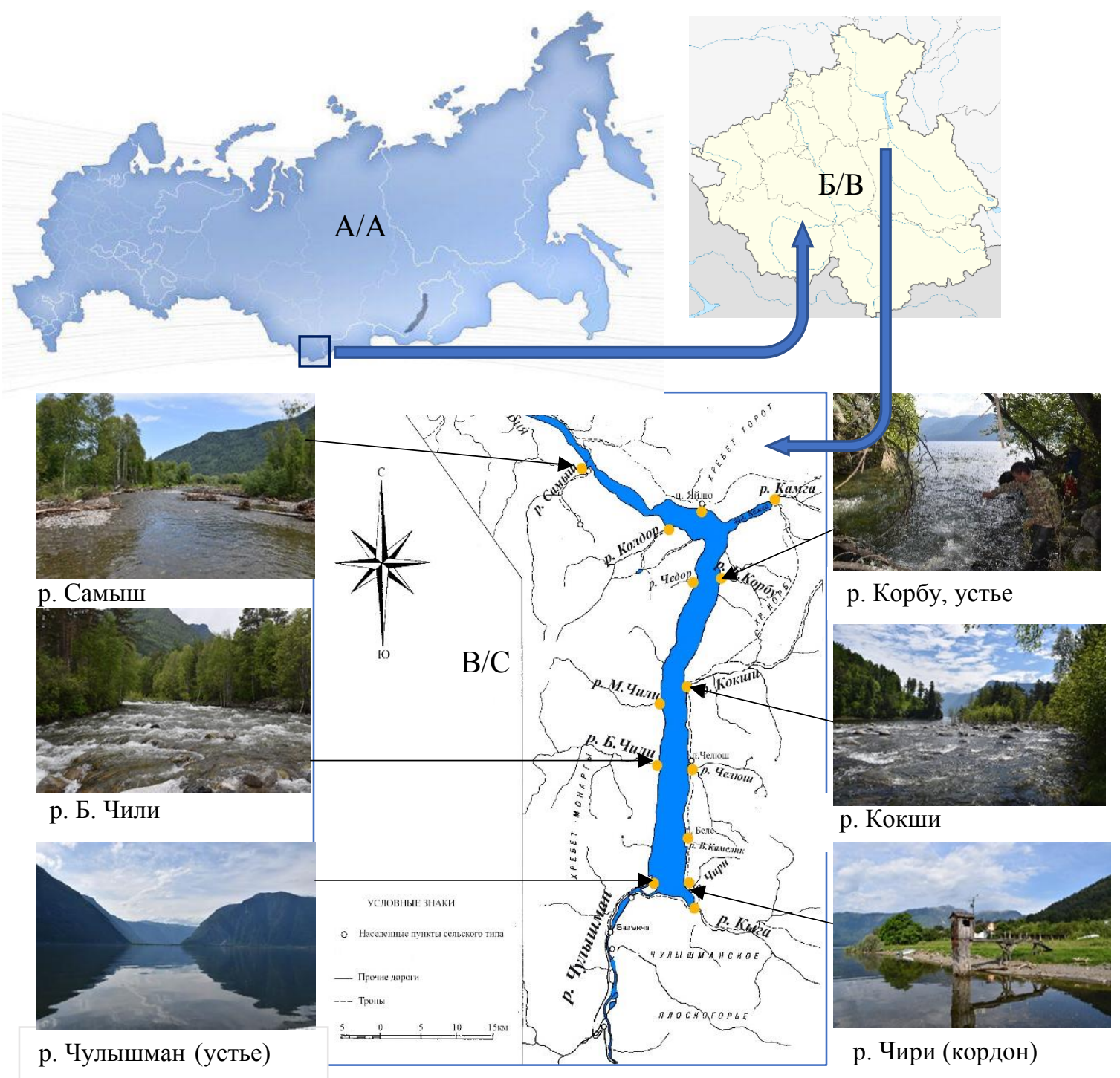

Pис. 1. Местоположение района исследования: А) на карте Российской Федерации; Б) на карте Республики Алтай; В) озеро Телеикое и его притоки, карта-схема отбора проб

Fig. 1. Location of the research area: A) on the map of the Russian Federation; B) on the map of the Altai Republic; C) Lake Teletskoe and its tributaries, sampling scheme map

Климат бассейна озера в целом континентальный с продолжительной зимой, смягченной фёнами, и коротким летом. Орографическая изолированность и процессы местной циркуляции создают здесь особый «лимнологический» климат. В противоположных оконечностях озера климатические характеристики довольно сильно отличаются: в южной части Телецкого озера теплее и выпадает в два раза меньше осад- ков (450-500 мм), чем в в северной части (до 1000 мм) $[12,13]$.

Водосборный бассейн озера оказывает существенное влияние на гидрологию и гидрохимию воды: отношение площади водного зеркала к площади водосбора равно 1:90 (например, для Байкала это соотношение составляет всего 1:17) [12]. Берега озера скальные и обрывистые, гранитного и сланцевого состава, 
или сложены крупными валунами, обломочным материалом. Песчаные и галечные берега наблюдаются в устьях рек Чулышман, Кыга, Кокши, Колдор, Самыш.

В ландшафтной структуре бассейна Телецкого озера в целом преобладают лесные сообщества, залесенность бассейна озера составляет более 50 \% и увеличивается с юга на север [12]. На севере преобладают кедрово-пихтовые леса с примесью сосны, а на юге - кедрово-лиственничные. Существует мнение, что именно в лесных водосборах корреляция между потоками вещества и химическими характеристиками воды наиболее сильная [5]. Обширные территории бассейнов некоторых притоков Телецкого озера заболочены.

Почвенный покров бассейна озера характеризуется четкой вертикальной зональностью и широтной поясностью, присущей горным областям. Восточные (правые) притоки Телецкого озера преимущественно дренируют экзарационно-денудационные склоновые поверхности с каменистыми примитивными горнотундровыми и горно-луговыми почвами. В бассейнах западных (левых) притоков озера в большей степени представлены кедрово-таежные лесные сообщества с горно-лесными бурыми типичными и оподзоленными, реже дерново-подзолистыми и серыми, лесными почвами [15] на мощных и переработанных осадочных породах. В южной части бассейна озера, в бассейне р. Чулышман, занимающем более 80 \% площади водосбора озера, почвенный покров, из-за разнообразия биогеохимических условий в пределах высотной поясности, отличается существенной неоднородностью.

Объектами нашего исследования являлись: наиболее крупный приток озера - река Чулышман, правый крупный приток широтной части озера - река Камга, крупный приток южной оконечности озера - река Кыга. В широтной части озера были исследованы реки Колдор и Самыш, в меридиональной части на западном берегу - реки Большие и Малые Чили, а также малая река Чедор, на восточном - крупная река Кокши, малые реки - Корбу, Челюш, Чири, а также ручей В. Камелик (рис. 1). Некоторые реки в устьевой части образуют конусы выноса и сразу за береговой полосой заболочены (Чулышман, Кыга, Камга, Колдор, Самыш), а другие практически не имеют долин, впадают в озеро водопадом (р. Корбу). В самом озере пробы воды отбирались в его северной (широтной) части у поселка Яйлю.

Телецкое озеро является одним из основных туристических объектов Алтая. Поселки Артыбаш и Яйлю (широтная часть озера), бассейны рек Чулышман, Большие и Малые Чили (западный берег) в летний период подвергаются существенной рекреационной нагрузке. В бассейнах рек Иогач и Самыш (северная, широтная часть озера) происходят вырубки кедрового леса, а до середины XX в. здесь велась добыча золота (прииск Калычак). Восточная часть территории озера Телецкое входит в Алтайский государственный природный заповедник, и антропогенная нагрузка на окружающую среду здесь заметно ниже, за исключением участка возле водопада на р. Корбу, притягивающего каждый год внимание тысяч туристов.
В дополнении к туристической нагрузке на окружающую среду Телецкого озера может добавиться промышленная, поскольку не так давно поднимался вопрос о возможности строительства золотоизвлекательной фабрики в районе с. Артыбаш. Добыча золота вблизи Телецкого озера, несомненно, будет наносить определенный ущерб экологической целостности природной территории.

Все это подчеркивает актуальность исследования химического состава компонентов природных ландшафтов Телецкого озера в настоящее время, важность изучения биогеохимической обстановки в его водосборном бассейне, необходимость оценки степени устойчивости системы «вода - водосборный бассейн».

\section{Методы исследования}

Исследование основных компонентов ионного состава вод притоков озера Телецкое нами проводилось в 2016-2019 гг. Пробы воды из притоков озера Телецкое отбирали в периоды весенне-летнего половодья и осенней межени в чистую полиэтиленовую посуду в устьевой части рек, где наблюдается максимальная минерализация воды и наиболее интенсивный вынос химических элементов. Пробы, в которых предполагалось определение $\mathrm{Fe}$, фильтровали через мембранный фильтр, консервировали $\mathrm{HNO}_{3}$ (2 мл на 0,5 л) согласно методике [16], транспортировали в темных контейнерах.

Определение ионного состава поверхностных вод проводили по стандартным методикам [16]: Cl-ион меркурометрическим методом, жесткость воды и кальций - комплексонометрическим (титровали трилоном Б), магний рассчитывали по разнице. Гидрокарбонаты оттитрованы раствором серной кислоты. Сульфаты определены турбодиметрически на спектрофотометре. $\mathrm{pH}$ вод определены потенциометрически. $\mathrm{Na}$ и К в 2016 и 2017 гг. определяли по разнице, а в 2018 и 2019 гг. - методом атомно-эмиссионной спектрометрии в Химико-аналитическом центре ИГиМ СО РАН на приборе IRIS Advantage Thermo Jarrell Ash corp. (1999). Содержание Fe в водах и водных вытяжках из почв определяли методом атомноабсорбционной спектрометрии в химикоаналитическом центре ИВЭП СО РАН с использованием электротермической атомизации на приборе SOLAAR M-6. Для калибровок прибора использовали стандартные растворы ГСО, контроль правильности определений проводили с помощью метода добавок.

Всего было отобрано и проанализировано более 80 проб воды.

Статистическую обработку данных проводили стандартными методами в Excel: рассчитывали среднее арифметическое, стандартное отклонение $\sigma=\sqrt{\frac{(x-\bar{x})^{2}}{(n-1)}}$ и ошибку средней $\left(\frac{\sigma}{\sqrt{n}}\right)$, коэффициенты вариации $\left(\frac{\sigma}{x} \times 100 \%\right)[17]$.

Данные о погоде в периоды, предшествующие отборам проб, были получены с сайта rp5.ru; архив данных найден только по метеостанции Артыбаш. 
Интенсивность химической денудации разных по величине речных бассейнов оценивали по величине модуля ионного стока - количеству растворимого вещества (т), переносимого с единицы площади водосборного бассейна $\left(\right.$ км $\left.{ }^{2}\right)$ в единицу времени, по формуле $\mathrm{M}_{\text {ions }}=(\mathrm{Q} / \mathrm{F}) \times \mathrm{C}$, где $\mathrm{Q}$ - расход воды (л/с); F - площадь водосбора $\left(\mathrm{kм}^{2}\right) ; \mathrm{C}$ суммарное содержание главных ионов, мг/л. Для расчетов использовались полученные нами данные о содержании главных ионов в водах, а также данные о среднесуточных расходах воды, $\mathrm{M}^{3} / \mathrm{c}$ [14].

\section{Результаты исследования и обсуждение}

По результатам наших исследований общее содержание водорастворимых солей в водах притоков озера Телецкое очень невысокое и варьирует в пределах от 18 до 159 мг/л (табл. 1). Большинство изученных рек несут воды с содержанием водорастворимых солей в среднем от 55 до 114 мг/л. По классификации С.Л. Шварцева исследуемые воды можно отнести к классу пресных вод, подклассу умеренно пресных. По результатам наших предыдущих исследований среднее содержание водорастворимых солей в притоках озера Телецкое в 2009 г. составляло 106 мг/л [18]. Для сравнения, в водах ручьев и рек бассейна $\mathrm{p}$. Мульта (Центральный Алтай) в 2008 г. значения общей минерализации вод были заметно ниже и не превышали 45 мг/л (в случае преимущественно грунтового их питания), а в водотоках, имеющих ледниковое питание, общая минерализация не превышала 20 мг/л [19].

В воде большинства притоков озера Телецкое содержание гидрокарбонат-иона изменяется от 30 до
100 мг/л, хлоридов - от 0,7 до 6,3 мг/л, сульфатов - от 3 до 12 мг/л, кальция - от 8 до 24 мг/л, магния - от 1,2 до 4,8 мг/л; преобладающим анионом является гидрокарбонат-ион, а среди катионов доминирует кальций. По литературным данным, в поверхностных водах Восточной Сибири среди главных ионов, как правило, также преобладают $\mathrm{HCO}_{3}^{-}, \mathrm{Ca}^{2+}$ и $\mathrm{Mg}^{2+}$, однако часто в заметно более высоких концентрациях [20].

Показатели ионного состава воды притоков озера Телецкое сравнимы с данными по ионному составу вод высокогорной реки Актру (Юго-Восточный Алтай), берущей свое начало с ледников [21], - в ее устье содержание гидрокарбонатов составляет 83 мг/л, сульфатов 25 мг/л, хлоридов 1,5 мг/л, кальция 25,3 мг/л, магния 7,4 мг/л и натрия 6,4 мг/л. Таким образом, содержание $\mathrm{SO}_{4}{ }^{2+}, \mathrm{Mg}^{2+}$ и $\mathrm{Na}^{+}$в воде устья p. Актру немного выше, чем в водах большинства притоков озера Телецкое, тогда как хлоридов в водах в устье р. Актру содержится меньше.

Наименьшее содержание водорастворимых солей обнаруживалось в водах рек Корбу и Кокши восточного берега меридиональной части озера, берущих свое начало на хребте Корбу, сложенном гранитами. Наши данные согласуются с результатами более ранних исследований химического состава притоков Телецкого озера [22]. Отметим, что за 8 лет уровень общей минерализации воды р. Корбу вырос почти в 1,5 раза, с 24,8 мг/л (осень 2009 г., согласно [22]) до 33,8 мг/л (осень 2017 г.), что можно объяснить усиливающимся влиянием рекреационной нагрузки.

Таблица 1. Ионный состав и суммарное содержание основных ионов в водах притоков озера Телецкое, мг/л, по данным за 2016-2019 гг. (в числителе - среднее 士ошибка средней, в знаменателе - диапазон значений)

Table 1. Ionic composition and total content of major ions in the waters of the Teletskoe tributaries, $m g / L$, according to data for 2016-2019 (in the numerator - the mean \pm the error of the mean, in the denominator - the range of values)

\begin{tabular}{|c|c|c|c|c|c|c|c|}
\hline Реки/Rivers & $\mathrm{HCO}_{3}^{-}$ & $\mathrm{Cl}^{-}$ & $\mathrm{SO}_{4}{ }^{2-}$ & $\mathrm{Ca}^{2+}$ & $\mathrm{Mg}^{2+}$ & $\mathrm{Na}^{+}+\mathrm{K}^{+}$ & $\Sigma$ \\
\hline \multicolumn{8}{|c|}{ Восточные притоки/Eastern tributaries } \\
\hline Камга & $48,1 \pm 2,9$ & $2,2 \pm 0,3$ & $\underline{5,5 \pm 0,6}$ & $12,8 \pm 0,5$ & $3,1 \pm 0,3$ & $1,6 \pm 0,3$ & $73,4 \pm 3,3$ \\
\hline Kamga & $39,6 \ldots 61,0$ & $1,4 \ldots 4,2$ & $3,1 \ldots 8,7$ & $8,0 \ldots 16,0$ & $2,4 \ldots 4,8$ & $\overline{0,5 \ldots 3,1}$ & $62,8 \ldots 88,8$ \\
\hline Корбу & $13,5 \pm 1,5$ & $2,8 \pm 0,4$ & $4,5 \pm 0,6$ & $2,7 \pm 0,5$ & $1,0 \pm 0,1$ & $\underline{3,9 \pm 0,6}$ & $28,3 \pm 1,6$ \\
\hline Korbu & $\overline{9,2 \ldots 18,3}$ & $\overline{2,1 \ldots 4,9}$ & $\overline{3,1 \ldots 7,3}$ & $\overline{1,2 \ldots 4,0}$ & $\overline{0,5 \ldots 1,2}$ & $2,4 \ldots 6,5$ & $\overline{22,0 \ldots 33,8}$ \\
\hline Кокши & $13,1 \pm 1,6$ & $\underline{1,9 \pm 0,4}$ & $\underline{5,3 \pm 0,6}$ & $3,4 \pm 0,4$ & $1,8 \pm 0,2$ & $1,6 \pm 0,2$ & $27,1 \pm 2,0$ \\
\hline Kokshi & $\overline{6,1 \ldots 18,3}$ & $\overline{0,7 \ldots 4,2}$ & $\overline{3,1 \ldots 9,1}$ & $\overline{2,0 \ldots 5,0}$ & $\overline{1,2 \ldots 2,4}$ & $0,26 \ldots 2,8$ & $\overline{18,6 \ldots 34,1}$ \\
\hline Челюш & $19,3 \pm 2,0$ & $1,6 \pm 0,4$ & $4,6 \pm 0,4$ & $\underline{4,5 \pm 0,4}$ & $\underline{2,0 \pm 0,3}$ & $1,5 \pm 0,1$ & $33,6 \pm 2,5$ \\
\hline Chelyush & $12,2 \ldots 24,4$ & $0,4 \ldots 3,5$ & $3,1 \ldots 6,4$ & $3 \overline{3,0 \ldots 6,0}$ & $1,0 \ldots 3,6$ & $\overline{0,9 \ldots 2,2}$ & $22,0 \ldots 42,1$ \\
\hline Кыга & $\underline{59,2 \pm 4,1}$ & $\underline{3,3 \pm 0,7}$ & $6,1 \pm 1,1$ & $17,6 \pm 1,5$ & $\underline{3,0 \pm 0,4}$ & $1,9 \pm 0,3$ & $91,1 \pm 6,8$ \\
\hline Kyga & $\overline{42,7 \ldots 64,1}$ & $\overline{2,1 \ldots 6,0}$ & $\overline{3,1 \ldots 9,1}$ & $1 \overline{2,0 \ldots 20,0}$ & $\overline{2,4 \ldots 4,2}$ & $\overline{1,1 \ldots 2,8}$ & $6 \overline{5,1 \ldots 104,6}$ \\
\hline Чири & $\underline{38,1 \pm 2,9}$ & $\underline{2,1 \pm 0,5}$ & $\underline{3,8 \pm 0,5}$ & $10,3 \pm 1,4$ & $2,5 \pm 0,8$ & $\underline{0,9 \pm 0,2}$ & $\underline{55,8 \pm 6,0}$ \\
\hline Chiri & $30,1 \ldots 42,7$ & $1,4 \ldots 3,5$ & $\overline{3,1 \ldots 5,3}$ & $8,0 \ldots 13,2$ & $1,2 \ldots 4,8$ & $\overline{0,5 \ldots 1,5}$ & $3 \overline{9,0 \ldots 63,5}$ \\
\hline В. Камелик & $\underline{81,8 \pm 5,7}$ & $2,7 \pm 0,7$ & $11,0 \pm 0,4$ & $24,7 \pm 2,8$ & $\underline{6,0 \pm 0,5}$ & $1,5 \pm 0,3$ & $128,1 \pm 8,6$ \\
\hline V. Kamelik & $6 \overline{1,0 \ldots 103,7}$ & $1,4 \ldots 3,5$ & $\overline{9,7 \ldots 12,5}$ & $\overline{12,0 \ldots 32,0}$ & $\overline{4,8 \ldots 7,2}$ & $\overline{0,9 \ldots 2,2}$ & $9 \overline{93,6 \ldots 159,0}$ \\
\hline \multicolumn{8}{|c|}{ Западные притоки/Western tributaries } \\
\hline Колдор & $79,3 \pm 12,2$ & $\underline{0,9 \pm 0,2}$ & $\underline{6,7 \pm 0,5}$ & $22,0 \pm 2,0$ & $\underline{3,0 \pm 0,6}$ & $2,6 \pm 0,8$ & $114,4 \pm 15,0$ \\
\hline Koldor & $\overline{67,1 \ldots 91,5}$ & $\overline{0,7 \ldots 1,1}$ & $\overline{6,2 \ldots 7,2}$ & $\overline{20,0 \ldots 24,0}$ & $\overline{2,4 \ldots 3,6}$ & $\overline{1,8 \ldots 3,4}$ & $\overline{99,6 \ldots 129,5}$ \\
\hline Самыш & $\underline{76,3 \pm 6,8}$ & $\underline{2,9 \pm 0,7}$ & $\underline{7,7 \pm 1,2}$ & $22,0 \pm 2,2$ & $\underline{3,8 \pm 0,3}$ & $1,7 \pm 0,5$ & $113,8 \pm 9,9$ \\
\hline Samysh & $58,0 \ldots 97,7$ & $1,8 \ldots 4,2$ & $4,6 \ldots 9,6$ & $16,0 \ldots 30,0$ & $3,6 \ldots 4,8$ & $0,5 \ldots 3,2$ & $87,0 \ldots 148,9$ \\
\hline Чедор & $\underline{62,5 \pm 4,6}$ & $\underline{4,6 \pm 0,3}$ & $\underline{8,6 \pm 2,5}$ & $21,0 \pm 1,0$ & $\underline{3,0 \pm 0,6}$ & $\underline{0,8 \pm 0,3}$ & $\underline{100,4 \pm 2,4}$ \\
\hline Chedor & $58,0 \ldots 67,1$ & $4,2 \ldots 4,9$ & $6,1 \ldots 11,0$ & $20,0 \ldots 22,0$ & $2,4 \ldots 3,6$ & $0,5 \ldots 1,1$ & $97,7 \ldots 102,9$ \\
\hline М. Чили & $\underline{53,5 \pm 2,7}$ & $2,3 \pm 0,4$ & $\underline{4,4 \pm 0,6}$ & $\underline{14,4 \pm 1,2}$ & $\underline{2,9 \pm 0,4}$ & $1,6 \pm 0,2$ & $79,3 \pm 4,1$ \\
\hline M. Chili & $42,7 \ldots 67,9$ & $\overline{0,7 \ldots 4,2}$ & $\overline{3,1 \ldots 7,2}$ & $\overline{8,0 \ldots 18,0}$ & $\overline{1,2 \ldots 3,6}$ & $0,5 \ldots 2,8$ & $7 \overline{1,5 \ldots 100,3}$ \\
\hline Б. Чили & $\underline{59,0 \pm 2,4}$ & $\underline{2,3 \pm 0,5}$ & $\underline{5,1 \pm 0,5}$ & $17,4 \pm 0,7$ & $2,5 \pm 0,3$ & $1,4 \pm 0,2$ & $\underline{88,3 \pm 3,0}$ \\
\hline B. Chili & $\overline{48,8 \ldots 70,2}$ & $\overline{1,1 \ldots 4,9}$ & $\overline{3,5 \ldots 6,8}$ & $\overline{14,0 \ldots 21,0}$ & $\overline{1,2 \ldots 4,8}$ & $\overline{0,6 \ldots 2,1}$ & $7 \overline{1,5 \ldots 100,3}$ \\
\hline Чулышман & $\underline{59,6 \pm 6,5}$ & $\underline{3,2 \pm 0,5}$ & $6,0 \pm 0,6$ & $17,0 \pm 1,6$ & $\underline{3,0 \pm 0,6}$ & $1,5 \pm 0,2$ & $\underline{88,7 \pm 9,2}$ \\
\hline Chulyshman & $36,6 \ldots 79,3$ & $2,1 \ldots 6,3$ & $4,1 \ldots 8,5$ & $\overline{12,0 \ldots 24,0}$ & $\overline{1,2 \ldots 4,8}$ & $1,0 \ldots 2,9$ & $5 \overline{7,2 \ldots 124,2}$ \\
\hline \multicolumn{8}{|c|}{ Район пос. Яйлю/Yaylu settlement area } \\
\hline Озер & $\underline{58,6 \pm 2,9}$ & $2,5 \pm 0,5$ & $\underline{5,8 \pm 0,5}$ & $17,0 \pm 0,7$ & $2,7 \pm 0,4$ & $\underline{2,0 \pm 0,2}$ & $\underline{88,5 \pm 3,8}$ \\
\hline Lake water & $48,8 \ldots 73,2$ & $\overline{0,7 \ldots 4,2}$ & $\overline{3,1 \ldots 8,2}$ & $1 \overline{4,0 \ldots 20,0}$ & $\overline{1,2 \ldots 4,8}$ & $\overline{1,3 \ldots 3,2}$ & $7 \overline{5,6 \ldots 106,4}$ \\
\hline
\end{tabular}


Известно, что средняя концентрация $\mathrm{CaO}$ в осадочной толще равна $15,9 \%$, а в гранитном слое земной коры - всего $2,7 \%$ [2], поэтому реки, дренирующие осадочные толщи, и реки, дренирующие магматические породы, отличаются по химическому составу и соотношению главных ионов в водах. Реки восточного берега рек Корбу и Кокши, берущие свое начало с одной гранитной вершины, заметно отличаются от других притоков озера и по соотношению главных ионов. В их водах долевое участие натрия и калия в ионной композиции более существенно (рис.
2), чем в водах противоположных западных притоков, дренирующих преимущественно осадочные толщи и потому несущих воды, в которых преобладают гидрокарбонаты и кальций.

Невысоким суммарным содержанием ионов характеризуется и другой восточный приток меридиональной части озера - p. Челюш, питающийся от снежников с гольцов (табл. 1). По данным 40-летней давности [23], общая минерализация вод в р. Челюш была немного выше (50-80 мг/л), чем в настоящее время.

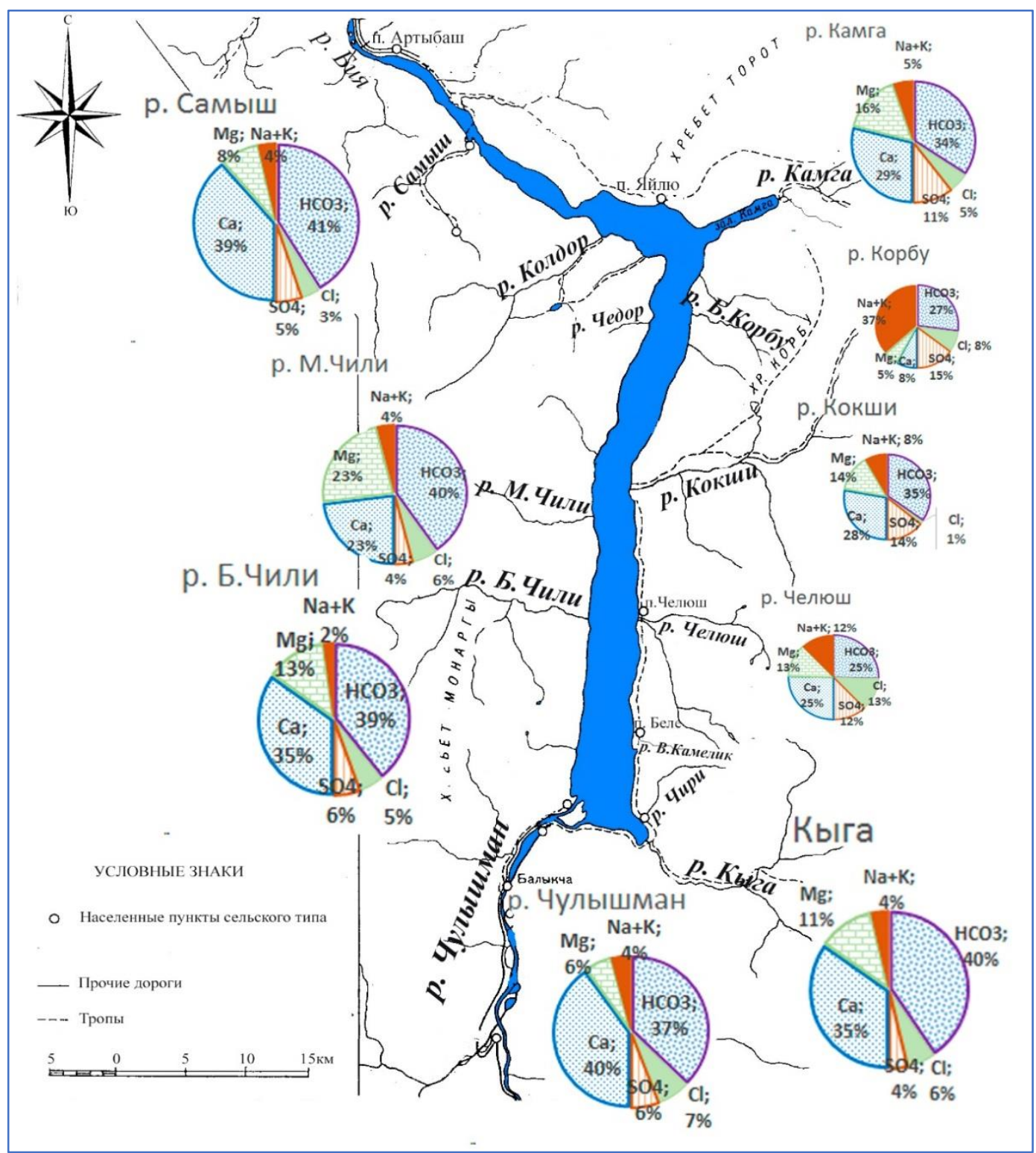

Рис. 2. Долевое участие главных ионов в формировании ионного состава вод притоков озера Телецкое, в \%-экв. (площади круговых диаграмм пропорииональны уровню общей минерализачии вод)

Fig. 2. Share of the major ions in the ionic composition of the tributaries waters of Lake Teletskoe (the areas of the pie charts are proportional to the TDS)

Более крупные притоки озера Телецкое (реки Кыга и Камга) характеризуются заметно более высоким уровнем общей минерализации вод. Но самое высокое суммарное содержание главных ионов каждый год фиксируется нами в воде малого восточного при- тока озера - ручья Камелик, который питается в основном подземными высокоминерализоваными водами. Максимальное значение общей минерализации его вод (159 мг/л осенью 2017 г.) совпадает с данными 1979 г. [23]. 
Сравнительно высокое общее содержание главных ионов отмечено в водах рек северной (широтной) части озера - в р. Самыш (до 148,9 мг/л осенью 2018 г.) и р. Колдор (до 129,5 мг/л осенью 2019 г.), несмотря на то, что в этой части озера водосборы отличатся большей (по сравнению с южной частью озера) степенью залесённости. Повышенный уровень общей минерализации вод рек северной части озера объясняется многочисленными вырубками в их бассейнах, что приводит к нарушению почвенного покрова кедровых массивов, усилению в них процессов денудации и смыва вещества и химических соединений, чему способствует большие (по сравнению с южной частью озера) количества осадков. Возможный запуск работы золотоизвлекательной фабрики в бассейне реки Самыш, несомненно, приведет к дополнительному активному поступлению химических элементов и соединений (каких именно - будет зависеть от технологии извлечения) в речную сеть.
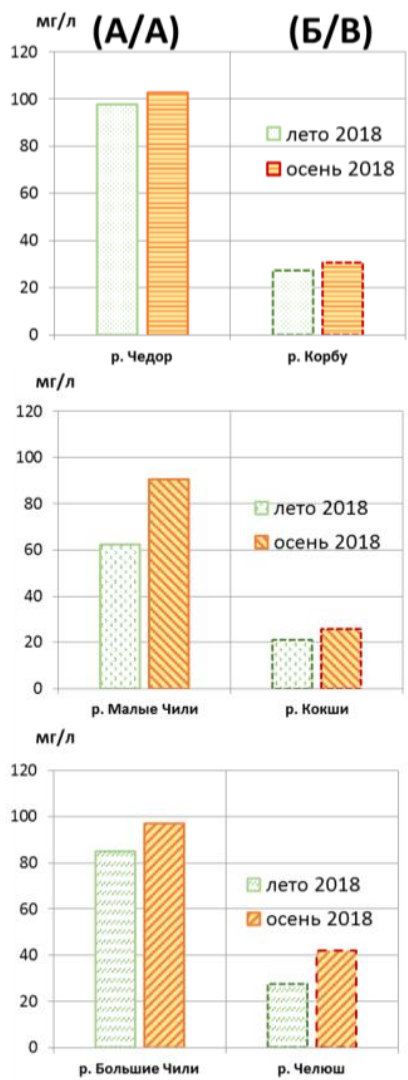

Pис. 3. Уровни общей минерализации вод противоположных притоков (А) западного и (Б) восточного берегов меридиональной части Телеикого озера в различные гидрологические периоды (весенне-летнего половодья и осенней межени) 2018 г.

Fig. 3. Total mineralization of the waters of the opposite tributaries $(A)$ of the western and $(B)$ eastern shores of the meridional part of Lake Teletskoe in various hydrological periods (spring-summer high water and autumn low water), in 2018

По результатам нашего исследования противоположные друг другу реки меридиональной части озера весьма существенно различаются по уровню общей минерализации вод. Так, на графиках (рис. 3) приведено суммарное содержание солей в «парных» реках: Чедор (западный приток) и Корбу (восточный приток), Малые Чили (слева) и Кокши (справа), Большие Чили (слева) и Челюш (справа), за два гидрологических периода (2018 г., лето и осень). Заметно, что более насыщены главными ионами воды западных притоков (рис. 3, А). Это объясняется тем, что дренируют они в основном берега с более зрелыми и сформированными горно-лесными почвами на мощных рыхлых осадочных отложениях. В водосборных бассейнах восточных притоков, стекающих со скалистых склонов, в большей степени представлены примитивные каменистые почвы на породах гранитного состава, поэтому воды правых притоков менее насыщены растворимыми солями.

Различия между западными и восточными притоками по содержанию главных ионов в водах, возможно, является и результатом нарастающего антропогенного воздействия на окружающую среду со стороны туристических объектов на западном берегу озера, в устьях рек Б. Чили, М. Чили, Чулышман.

Сезонная динамика общей минерализации вод изученных нами притоков озера выражена довольно отчетливо и в основном соответствует внутригодовому изменению водности: в период осенней межени, когда в общую минерализацию вод вносят вклад грунтовые воды, уровень содержания главных солей заметно выше, чем в период весенне-летнего половодья, когда происходит приток талых ледниковых вод (рис. 4)

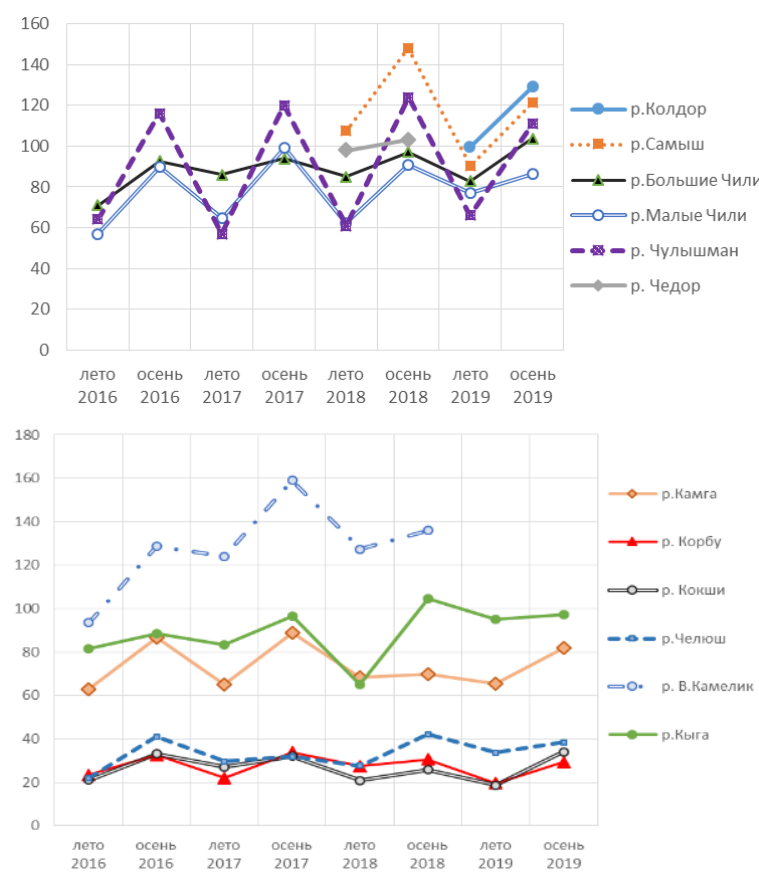

Pис. 4. Сезонная динамика общей минерализации вод западных (слева) и восточных (справа) притоков озера Телеикое

Fig. 4. Seasonal dynamics of the total mineralization of the waters of the western (left) and eastern (right) tributaries of Lake Teletskoe 
На долю гидрокарбонат-иона в водах притоков озера Телецкое приходится, как правило, от 62 до $90 \%$ от общего (в мг-экв./л) содержания анионов. В водах восточных притоков меридиональной части реках Корбу, Кокши - содержание гидрокарбонатиона заметно ниже, его доминирование не так выражено: 31-73\%-экв. (рис. 2).

Считается, что сезонные колебания концентрации и соотношения нативных ингредиентов в природных водоемах существенно не изменяются в течение большей части года и не зависят от стока [24-26], за исключением штормовых событий [25], тогда как содержания компонентов, имеющих частично антропогенное происхождение, могут существенно колебаться [24, 26]. Отметим, что величины коэффициентов вариации средних содержаний $\mathrm{HCO}_{3}^{-}$и $\mathrm{Ca}^{2+}$ в водах большинства притоков озера наименьшие, что подтверждает природные источники поступления этих ионов в воды. При этом содержание хлорид-иона в водах притоков озера Телецкое варьирует наиболее существенно, $\mathrm{Cv}=43-62 \%$, что, возможно, указывает на его частично «неконсервативное» [24] происхождение. Наиболее высоким содержанием хлоридов в воде отличаются реки южной оконечности озера - p. Чулышман и р. Кыга. Установлено, что в водах восточных притоков (реках Корбу, Кокши, берущих свое начало с гранитного хребта Корбу) на долю хлоридов приходится до 37 \%-экв., тогда как в водах западных притоков - не более 12 \%-экв. Считается, что более существенная роль хлорид-иона в уровне общей минерализации природных вод связана с его более интенсивным выщелачиванием из горных пород гранитного состава [23].

Содержание сульфатов в водах притоков озера Телецкое относительно невысокое и за весь изученный период не превышает 13,5 мг/л. По результатам нашего исследования наиболее высоким содержанием $\mathrm{SO}_{4}{ }^{2-}$ в водах отличается ручей Камелик, от 9,7 до 12,5 мг/л (12-16 \%-экв.), что объясняется присутствием сульфидов в зоне контакта гранитов и метаморфических сланцев [23]. Довольно высоким содержанием сульфатов в водах отличаются также реки Чедор и Колдор.

В течение года содержание сульфатов в водах большинства притоков Телецкого озера существенно не изменятся. Однако в самом крупном притоке озера p. Чулышман содержание сульфатов от лета к осени, как правило, возрастает в 1,5-2 раза. В последние годы отмечен некоторый рост содержания сульфатов в воде в реках Корбу и Кокши - до 7,3 в р. Корбу осенью 2018 г. и до 9,1 мг/л в р. Кокши осенью 2019 г.

Участие кальция в формировании катионного состава вод притоков озера Телецкое, как правило, значительно (рис. 2): 60-85 \%-экв., при содержании от 0,6 до 32 мг/л. Наиболее высоким содержанием кальция в воде отличается ручей В. Камелик, а также крупные притоки северной части озера - реки Колдор и Самыш (табл. 1). Концентрация магния в водах притоков озера Телецкое невысокая - как правило, от 0,5 до 4,8 мг/л (7,2 мг/л отмечалось в р. В. Камелик).

Повышенным содержанием $\mathrm{Na}^{+}$и $\mathrm{K}^{+}$отличаются воды р. Корбу. В 2018 г. содержание $\mathrm{K}^{+}$в водах p. Корбу составляло 6 мг/л, а $\mathrm{Na}^{+}-2,9$ мг/л. На долю суммарного содержания натрия и калия в водах большинства притоков озера Телецкое приходится, как правило, не более 2-11 \%-экв. от общего содержания катионов, но в воде в р. Кокши этот показатель составляет 10-29 \%-эКв., а в р. Корбу - 32-73 \%-эКв. (рис. 2)

Калий более прочно, чем натрий и кальций, удерживается в пределах Мировой суши, поскольку большая его часть при гипергенной перестройке кристаллохимических структур силикатов остается в составе вновь образованных глинистых минералов. В осадочной оболочке средняя концентрация $\mathrm{K}_{2} \mathrm{O}$ равна $1,87 \%$, а в гранитном слое земной коры - 2,89 \% [2]. Считается, что в водосборах, где калий в основном поступает в воду в результате выветривания горных пород, его концентрация в водах рек с увеличением количества осадков и стока должна снижаться из-за процессов растворения, а в водосборах, где калий, будучи вовлеченным в биогеохимический круговорот, активно поступает в воды из верхних горизонтов почв, с увеличением осадков и стока его концентрация в водах рек возрастает [27]. По нашим данным, в 2018 г., когда была холодная и влажная осень (а за 4 дня до отбора проб в районе с. Артыбаш шли непрерывные дожди), в крупных западных притоках озера - реках Самыш, М. Чили и Б. Чили, содержание калия в водах (определенного атомно-эмиссионным методом) было существенно выше $(0,75,0,71$ и 0,35 мг/л соответственно), чем в 2019 г., когда наблюдалась сухая осень $(0,28,0,32$ и 0,25 мг/л соответственно). Можно предположить, что на северных берегах широтной части озера и на западных берегах меридиональной части озера, бассейны которых большей частью представлены горно-лесными ландшафтами с хорошо сформированными горно-лесными бурыми и дерново-подзолистыми почвами, калий интенсивнее вовлекается в биогеохимический круговорот и существенная его часть поступает в воды с поверхностным и внутрипочвенным стоком. В бассейнах восточных притоков чаще встречаются участки с примитивным каменистым почвенным покровом (реки Челюш, Кокши); влажной осенью 2018 г. содержание калия в их водах, наоборот, было почти в два раза ниже $(0,48$ и 0,31 мг/л), чем в сухую осень 2019 г. $(0,8$ и $0,58 \mathrm{мг} / л$ соответственно). То, что с увеличением количества осадков и стока концентрация калия в реках восточного берега озера снижается, возможно, свидетельствует о его поступлении в воды преимущественно в результате выветривания горных пород [25], что согласуется с предположениями А.М. Малолетко и Т.П. Шестаковой [23].

В пробах воды самого озера, дважды в год отбираемых у пос. Яйлю, суммарное содержание солей часто выше, чем в притоках, и варьирует в пределах 69,4...97,9 мг/л. Возможно, это объясняется повышенной (125-190 мг/л) минерализацией вод нескольких ручьев, впадающих в озеро вблизи поселка, которые, в свою очередь, питаются грунтовыми безнапорными водами рыхлых отложений высоких озерных террас [23] валунно-галечникового состава. В водах 
озера, как и в водах его притоков, среди анионов преобладают гидрокарбонаты, а среди катионов - кальций (табл. 1), однако стоит отметить, что в последние годы в водах оз. Телецкое в районе пос. Яйлю в формировании ионного состава воды выросло участие хлоридов, а, как известно, хлориды в континентальных водах имеют во многом животное происхождение и являются продуктом жизнедеятельности животных организмов [2]. Наиболее стабильно в водах озера содержание кальция, а наиболее существенно в зависимости от гидрологического периода варьирует содержание гидрокарбонатов и хлоридов.

Таблица 2. Содержание растворенного железа в водах притоков и в водной вытяжке из почв (верхние горизонты), мкг/л

Table 2. Iron content in tributaries waters and in water extract from soils (upper horizons), $m c \mathrm{~g} / \mathrm{l}$

\begin{tabular}{|c|c|c|c|}
\hline $\begin{array}{l}\text { Река } \\
\text { River }\end{array}$ & $\begin{array}{c}\text { Fe в водной вы- } \\
\text { тяжке почвы } \\
\mathrm{Fe} \text { in soil water } \\
\text { extraction } \\
\end{array}$ & $\begin{array}{l}\text { Fе в воде } \\
\text { Fe in water }\end{array}$ & $\begin{array}{c}\mathrm{Fe}(\text { вода)/ } \\
\mathrm{Fe}(\text { вод. выт. почв) } \\
\mathrm{Fe} \text { (water)/Fe (soil } \\
\text { water extraction) } \\
\end{array}$ \\
\hline \multicolumn{4}{|c|}{ Восточные притоки/Eastern tributaries } \\
\hline $\begin{array}{l}\text { Камга } \\
\text { Каmga }\end{array}$ & 520 & 210 & 0,40 \\
\hline $\begin{array}{l}\text { Корбу } \\
\text { Korbu }\end{array}$ & 580 & 270 & 0,47 \\
\hline $\begin{array}{l}\text { Кокши } \\
\text { Kokshi }\end{array}$ & 670 & 230 & 0,34 \\
\hline $\begin{array}{l}\text { Кыга } \\
\text { Kyga }\end{array}$ & 660 & 230 & 0,35 \\
\hline \multicolumn{4}{|c|}{ Западные притоки/Western tributaries } \\
\hline $\begin{array}{l}\text { Самыш } \\
\text { Samysh } \\
\end{array}$ & 1180 & 310 & 0,26 \\
\hline $\begin{array}{l}\text { Б. Чили } \\
\text { В. Chili }\end{array}$ & 1320 & 190 & 0,14 \\
\hline $\begin{array}{l}\text { М. Чили } \\
\text { M. Chili }\end{array}$ & 1530 & 210 & 0,14 \\
\hline $\begin{array}{l}\text { Чулышман } \\
\text { Chulyshman }\end{array}$ & 1670 & 200 & 0,12 \\
\hline
\end{tabular}

Содержание растворенного Fе в отфильтрованных пробах вод притоков озера Телецкое варьирует незначительно, от 210 до 310 мкг/л. Довольно высокие количества Fe в водах притоков озера Телецкое являются отражением биогеохимической обстановки в лесных и заболоченных ландшафтах водосборов, способствующей образованию его подвижных форм [2]. Наиболее высоким содержанием растворенного железа, превышающим ПДК в.х. (300 мкг/л), отличаются воды р. Самыш, что, возможно, является результатом и антропогенного воздействия на окружающую среду в бассейне реки.

В водных вытяжках из верхних горизонтов почв содержание железа изменяется от 520 до 1670 мкг/л (табл. 2), по этому показателю восточные и западные притоки существенно различаются. Различаются и соотношения содержаний микроэлементов в воде и в водной вытяжке почв западных и восточных притоков, что обусловлено различный биогеохимической обстановкой водосборных бассейнов. Так, в долинах западных притоков часто встречаются мелкие подпруженные и заболоченные озера [15], болотные массивы с кислой реакцией среды почв и восстанови- тельными условиями, благоприятными для образования подвижных форм железа [2]. Это определяет большую насыщенность почв западного берега Телецкого озера водорастворимым железом. Однако в силу буферной способности горно-таежных и горнолесных бурых почв западных берегов железо, очевидно, прочно фиксируется в составе почвенных микроагрегатов, образует комплексы с фульвокислотами и в меньших количествах попадает в воды дренирующих водотоков - соотношения $\mathrm{Fe}_{\text {вод }} / \mathrm{Fe}_{\text {почв }}$ здесь ниже. На восточном берегу, где более распространены литогенные почвенные образования, содержание водорастворимых форм железа в почвах заметно меньше, но при этом в поверхностных водах зачастую больше, поскольку крутые склоны и низкое содержание сорбирующих веществ в почвах восточных берегов озера благоприятствуют активному выносу растворимых форм железа в речную сеть.

Таблица 3. Гидрологические характеристики и расчетные величины ионного стока в притоках Телецкого озера с существующими гидрологическими постами

Table 3. Hydrological characteristics and calculated values of ion runoff in the tributaries of Lake Teletskoe on which there are hydrological posts

\begin{tabular}{|c|c|c|c|}
\hline $\begin{array}{l}\text { Характеристики, показатели } \\
\text { Characteristics, indicators }\end{array}$ & 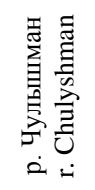 & 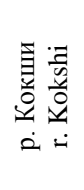 & 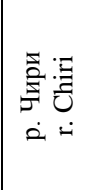 \\
\hline $\begin{array}{l}\text { Площадь водосбора, км² [12] } \\
\text { Catchment area, } \mathrm{km}^{2}[12]\end{array}$ & 17200 & 472 & 37 \\
\hline $\begin{array}{l}\text { Средняя высота водосбора, м [12] } \\
\text { Average catchment height, m [12] }\end{array}$ & 2040 & 1540 & 1630 \\
\hline $\begin{array}{l}\text { Длина реки, м [12] } \\
\text { River length, m [12] }\end{array}$ & 241 & 37 & 11 \\
\hline \begin{tabular}{|l|} 
Уклон реки, \% [14] \\
River slope, \% [14] \\
\end{tabular} & 8,6 & 18 & 150 \\
\hline $\begin{array}{l}\text { Среднегодовой расход воды, } \mathrm{m}^{3} / \mathrm{c}, 2018 \text { г. } \\
\text { [2] } \\
\text { Average annual water consumption, } \\
\mathrm{m}^{3} / \text { sec.. } 2018 \text { [2] }\end{array}$ & 175,8 & 16,2 & 0,69 \\
\hline $\begin{array}{l}\text { Объем стока, км }{ }^{3} \text { за год } \\
\text { Runoff volume, } \mathrm{km}^{3} \text { per year }\end{array}$ & 5,5 & 0,51 & 0,02 \\
\hline $\begin{array}{l}\text { Среднемесячный расход воды м³/c } \\
\text { (июнь/сентябрь) } \\
\text { Average monthly water consumption } \\
\mathrm{m}^{3} / \text { sec. (June/September) } \\
\end{array}$ & $\frac{728,0}{133,6}$ & $\frac{46,5}{22,9}$ & $\underline{2,9}$ \\
\hline $\begin{array}{l}\text { Объем стока, км }{ }^{3} \text { за июнь/за сентябрь } \\
\text { Runoff volume, } \mathrm{km}^{3} \text { per June/per September }\end{array}$ & $\frac{1,95}{0,36}$ & $\frac{0,125}{0,061}$ & $\frac{0,0077}{0,0016}$ \\
\hline $\begin{array}{l}\text { Модуль стока, л/с с км² в июне/в сентябре } \\
\text { Runnoff modulus, } 1 / \mathrm{sec}^{2} \text {. from } \mathrm{km}^{2} \text { in } \\
\text { June/in September }\end{array}$ & $\frac{42,3}{7,8}$ & $\underline{98,6}$ & $\frac{77,2}{16,2}$ \\
\hline $\begin{array}{l}\text { Общая минерализация воды, мг/дм³ } \\
\text { июнь/сентябрь } \\
\text { TDS, mg/l, June/September }\end{array}$ & $\frac{65,7}{124,2}$ & $\frac{20,9}{25,8}$ & $\frac{55,4}{65,4}$ \\
\hline $\begin{array}{l}\text { Ионный сток, т/год } \\
\text { Ion runoff, t/year }\end{array}$ & 364266 & 10683 & 1231 \\
\hline $\begin{array}{l}\text { Ионный сток, т/мес., за июнь/за сентябрь } \\
\text { Ion runoff, t/month, for June/for September }\end{array}$ & $\frac{128113}{44432}$ & $\frac{2605}{1568}$ & $\frac{424}{104}$ \\
\hline $\begin{array}{l}\text { Модуль ионного стока, т/ мес. с км², за } \\
\text { июнь/за сентябрь } 2018 \text { г. } \\
\text { Ion runoff modulus, t/month from } \mathrm{km}^{2} \text {, for } \\
\text { June/September } 2018\end{array}$ & $\frac{7,4}{2,6}$ & $\frac{5,5}{3,3}$ & $\frac{11,5}{2,8}$ \\
\hline $\begin{array}{l}\text { Модуль ионного стока, т/ год с км², } \\
2018 \text { г. } \\
\text { Ion runoff modulus, t/year, } 2018 \text { г. }\end{array}$ & 21,2 & 22,6 & 32,8 \\
\hline
\end{tabular}


На основании величин расхода воды [2] в тех притоках озера, на которых есть гидрологические посты, данных о площадях водосборов [12], а также полученных нами аналитических данных были рассчитаны показатели водного и ионного стока в 2018 г. для рек Чулышман, Кокши и Чири (табл. 3).

Согласно расчетам, величины ионного стока малого (р. Чири), среднего (р. Кокши) и крупного (р. Чулышман) притоков озера напрямую зависят от длины реки и площади водосбора и определяются в основном величинами объемов водного стока реки. За один год с водами реки Чулышман в озеро поступает 364 тыс. т основных растворимых солей, из них 219 тыс. т - гидрокарбонатов (60 \%) и 77 тыс. т кальция $(21 \%)$. Для сравнения, основные притоки Байкала в течение года в сумме приносят в озеро 6 млн т в год растворимых солей [28], из них почти $60 \%$ также приходится на гидрокарбонаты (3,5 млн т) и $14 \%$ на кальций $(0,8$ млн т). Среднемноголетний ионный сток бассейна Средней Оби составляет 18-24 млн т/год [29].

Показатели модуля ионного стока - количества растворимого вещества, выносимого в единицу времени с единицы площади водосборного бассейна в различных по величине притоках Телецкого озера, вполне сопоставимы. В малой реке Чири модуль ионного стока в 1,5 раза выше, чем в самом крупном притоке озера р. Чулышман. Летом меньше всего растворимых солей выносится с 1 км ${ }^{2}$ бассейна р. Кокши, зато в период осенней межени модуль ионного стока p. Кокши наибольший (табл. 4). Отметим, что с увеличением уклона реки интенсивность химической денудации увеличивается, однако с увеличением средней высоты водосбора этот показатель снижается, что указывает на относительную устойчивость к размыву горных пород [11], слагающих южное и восточное окаймление озера.

За год с 1 км$^{2}$ бассейнов разных по величине притоков озера Телецкого выносится от 21,2 до 32,8 т растворенных солей. В р. Чулышман минимальный среди сравниваемых рек модуль ионного стока объясняется сложной структурой водосборного бассейна: верховья и среднее течение реки Чулышман (в отличие от р. Чири) заняты не только горно-лесными, но и горно-тундровыми, горно-степными ландшафтами с менее интенсивным, чем в лесных сообществах, биологическим круговоротом. Из 21,2 т растворенных солей, выносимых с 1 км бассейна р. Чулышман, 12,8 т в год с км² приходится на гидрокарбонаты, 1,4 т с км $^{2}$ составляет вынос хлоридов, 1,6 т с км² водосбора выносится сульфатов, 4,5 т кальция и 0,4 т магния. Для сравнения, притоками р. Печора за год с 1 км водосборной площади выносится солей в 1,5 ..3 раза больше, например, 20,9..24.4 т гидрокарбонатов, 2,3..5,2 т хлоридов, 3,9..6,8 т сульфатов, 4,3 ..8,2 т кальция и $1,5 \ldots 2,3$ т магния [6].

Химические компоненты в водах притоков Телецкого озера по уменьшению величины ионного стока образуют следующий ряд: $\mathrm{HCO}_{3}^{-}>>\mathrm{Ca}^{2+}>\mathrm{SO}_{4}{ }^{2-}>\mathrm{Cl}^{-}$ $>\mathrm{Mg}^{2+}>\mathrm{Na}^{+}, \mathrm{K}^{+}$. Для притоков Байкала этот ряд выглядит немного иначе: $\mathrm{HCO}_{3}^{-}>>\mathrm{Ca}^{2+}>\mathrm{SO}_{4}{ }^{2-}>\mathrm{Na}^{+}$,
$\mathrm{K}^{+}>\mathrm{Mg}^{2+}>\mathrm{Cl}^{-}$[28], в ионный сток рек бассейна Телецкого озера сравнительно больший вклад вносят хлориды и магний.

\section{Заключение}

Общее содержание главных ионов в водах притоков Телецкого озера низкое, варьирует в пределах 18-159 мг/л и, как правило, увеличивается во время осенней межени, по сравнению с периодом весеннелетнего половодья.

Уровень общей минерализации в водах рек северной (широтной) части озера (p. Колдор, p. Самыш) с более залесенными водосборами в целом на 25 \% выше, чем в водах рек южной части озера (р. Чулышман, p. Кыга), что объясняется вырубками кедровых лесов, приводящими к нарушению почвенного покрова и усилению выноса химических веществ и соединений.

Общее содержание главных ионов в водах западных и восточных притоков меридиональной части озера различается в 2,5-3,5 раза, что является отражением различной геохимической обстановки на водосборах, разных биогеохимических процессов, а также результатом нарастающего антропогенного воздействия на окружающую среду со стороны туристических объектов на западном берегу озера.

Большинство притоков оз. Телецкое несут гидрокарбонатно-кальциевые воды. В ионный состав вод восточных притоков, берущих свое начало на гранитном хребте Корбу, больший вклад вносят $\mathrm{Cl}^{-}$и $\mathrm{SO}_{4}{ }^{2-}$, $\mathrm{K}^{+}$и $\mathrm{Na}^{+}$(до $37 \%$ \%-экв. $\mathrm{Na}^{+}+\mathrm{K}^{+}$в р. Корбу). В водах западных притоков, дренирующих большей частью осадочные отложения, выражено доминирование гидрокарбонатов и кальция.

В водах рек восточных берегов озера с преобладанием в структуре водосбора каменистых примитивных почв с увеличением количества осадков концентрация $\mathrm{K}^{+}$снижается в 1,7 раза из-за процессов растворения, что указывает на его поступление в поверхностные воды основном из горных некарбонатных пород. В водах западных рек, дренирующих хорошо сформированные горно-лесные почвы, с увеличением количества осадков и стока концентрация $\mathrm{K}^{+}$ увеличивается в 1,4-2,7 раза, что указывает на его активное здесь вовлечение в биогеохимический круговорот и поступление в воды этих рек в основном при вымывании из почвенных горизонтов.

Химическая денудация в бассейнах рек разной величины изменяется от 21 до 32 т/год с км², ее интенсивность с увеличением средней высоты водосбора и уменьшением уклона реки снижается, что указывает на относительную устойчивость к размыву горных пород южного и восточного окаймлений Телецкого озера. Наибольший модуль ионного стока установлен в малой реке Чири, а наименьший из сравниваемых рек - в самом крупном притоке озера р. Чулышман, что объясняется более сложной структурой его водосборного бассейна.

Работа выполнена в рамках государственного задания ИВЭП СО РАН по проекту № 0306-2021-0003 (№ гос. регистращии 1021032424138-9). 


\section{СПИСОК ЛИТЕРАТУРЫ}

1. Вернадский В.И. Биосфера и ноосфера. - М.: Айрис-пресс, 2012. -576 с.

2. Добровольский В.В. Основы биогеохимии. - М.: Высшая школа, 1998. - 413 с.

3. Resolving the double paradox of rapidly mobilized old water with highly variable responses in runoff chemistry / K. Bishop, J. Seibert, S. Köhler, H. Laudon // Hydrological Processes. 2004. - V. 18 - P. 185-189.

4. Impact of soil and groundwater heterogeneity on surface water chemistry in an upland catchment / M.I. Stutter, L.K. Deeks, D. Low, M.F. Billett // Journal of Hydrology. - 2006. - V. 318. P. 103-120.

5. Influence of catchment characteristics and flood type on relationship between streamwater chemistry and streamflow: case study from Carpathian Foothills in Poland / J.P Siwek, M. Zelazny, W. Chelmicki // Water Air and Soil Pollution. - 2011. - V. 214. P. 547-563.

6. Изменение интенсивности химической денудации на водосборе реки Печоры в условиях нестационарного климата и хозяйственной деятельности / А.О. Даниленко, О.С. Решетняк,

Л.С. Косменко, М.Ю. Кондакова // Вода и экология: проблемы и решения. - 2020. - № 4 (84). - С. 38-49.

7. Taboada-Castro M.M., Rodriguez-Blanco M.L., Taboada-Castro M.T. Assessing the influence of catchment land-use patterns on the nutrients and major ions chemistry of drainage water // Communications in Soil Science and Plant Analysis. - 2013. V. 44. - Iss. 1-4. - P. 422-428.

8. Geochemistry of the dissolved load of the Changjiang Basin Rivers: anthropogenic impacts and chemical weathering B. Chetelat, C.Q. Liu, Z.Q. Zhao, Q.L. Wang, S.L. Li, J. Li, B.L. Wang // Geochimica et Cosmochimica Acta. - 2008 . V. 72 (17). - P. 4254-4277.

9. Major element chemistry of the Huai River Basin, China / L. Zhang, X.F. Song, J. Xia, R.Q. Yuan, Y.Y. Zhang, X. Liu D.M. Han // Applied Geochemistry. - 2011. - V. 26. - Iss. 3. P. $293-300$

10. Catchment controls on solute export / A. Musolff, C. Schmidt, B. Selle, J.H. Fleckenstein, // Advances in water resources. 2015. - V. 86. - P. 133-146.

11. Абдуев М.А.О. Химическая денудация на горной территории Азербайджана // Водное хозяйство России: проблемы, технологии, управление. - 2016. - № 1. - С. 4-16.

12. Селегей В.В., Селегей Т.С. Телецкое озеро / под ред. В.А. Знаменского. - Л.: Гидрометеоиздат, 1978. - 142 с.

13. Маринин А.М., Самойлова Г.С. Физическая география Горного Алтая. - Барнаул: БГПИ, 1987. - 110 с.

14. Автоматизированная информационная система государственного мониторинга водных объектов (АИС ГМВО). URL: https:/gmvo.skniivh.ru/ (дата обращения 20.06.2021)

15. Черных Д.В., Самойлова Г.С. Ландшафты Алтая (Республика Алтай и Алтайский край) Карта М - 1:500000. - Новосибирск: Новосибирская картографическая фабрика, 2011.

16. Новиков Ю.В., Ласточкина К.О., Болдина 3.Н. Методы исследования качества воды водоемов / под ред. А.П. Шицковой. М.: Медицина, 1990. - 397 с.

17. Лакин Г.Ф. Биометрия. - М.: Высшая школа, 1990. - 351 с.

18. Влияние биогеохимической обстановки водосборных бассейнов на микроэлементный состав вод притоков Телецкого озеpa / А.В. Пузанов, С.В. Бабошкина, С.Я. Двуреченская, Т.А. Рождественская // Вода и экология: проблемы и решения. 2020. - № 3 (83). - С. 70-78.

19. Ефимова Л.Е., Повалишникова Е.С., Фролова Н.Л. Гидроэкологические особенности бассейна реки Мульты (Горный Алтай) // География и природные ресурсы. - 2011. - № 1. C. $34-42$.

20. Геохимические особенности природных вод бассейна реки Витим (западные районы Патомского нагорья) / Д.А. Новиков, А.А. Максимова, Д.В. Напреев, Ю.Г. Копылова, А.А. Хващевская // Известия Томского политехнического университета. Инжиниринг георесурсов. - 2021. - Т. 332. - № 8. - С. 7-17.

21. Условия выноса и аккумуляции химических элементов в горно-ледниковом бассейне Актру (Горный Алтай) / О.Г. Савичев, В.А. Домаренко, С.И. Арбузов, А.Я. Пшеничкин, Е.А. Вильгельм // Разведка и охрана недр. - 2019. - № 3. C. $55-62$.

22. Долматова Л.А. Особенности гидрохимического режима Телецкого озера в период осеннего охлаждения // Мир науки, культуры, образования. - 2011. - № 6 (31). - С. 417-423.

23. Малолетко А.М., Шестакова Т.П. Материалы к гидрохимии бассейна Телецкого озера // Вопросы географии Сибири. Томск: Изд-во ТГУ, 1979. - С. 110-126.

24. Khazheeva Z.I., Tulokhonov A.K., Dashibalova L.T. Seasonal and spatial dynamics of TDS and major ions in the Selenga river // Water Resources. - 2007. - V. 34. - № 4. - C. 444-449.

25. Hofmann H., Cartwright I., Morgenstern U. Estimating retention potential of headwater catchment using Tritium time series // Journal of Hydrology. - 2018. - V. 561. - P. 557-572

26. Cartwright I. Concentration vs. streamflow (C-Q) relationships of major ions in south-eastern Australian rivers: sources and fluxes of inorganic ions and nutrients // Applied Geochemistry. - 2020. V. 120. - № 104680. - P. 1-11.

27. Holloway J.M., Dahlgren R.A. Seasonal and event-scale variations in solute chemistry for four Sierra Nevada catchments // Journal of Hydrology. - 2001. - V. 250. - P. 106-121.

28. Галазий Г.И. Байкал в вопросах и ответах. - Иркутск: Восточно-Сибирское книжное издательство, 1987. - 167 с.

29. Савичев О.Г. Ионный сток Средней Оби и ее крупных притоков // Известия Томского политехнического университета. 2004. - T. 307. - № 6. - С. 40-44.

Поступила 02.07.2021 г.

\section{Информация об авторах}

Пузанов А.В., доктор биологических наук, профессор, директор Института Водных и экологических проблем CO PAH.

Бабошкина $\boldsymbol{C}$.В., кандидат биологических наук, старший научный сотрудник лаборатории биогеохимии Института Водных и экологических проблем СО РАН.

Рождественская T.A., кандидат биологических наук, старший научный сотрудник лаборатории биогеохимии Института Водных и экологических проблем СО РАН.

Балыкин C.H., кандидат биологических наук, старший научный сотрудник лаборатории биогеохимии Института Водных и экологических проблем СО РАН.

Балыкин Д.Н., кандидат сельскохозяйственных наук, научный сотрудник лаборатории биогеохимии Института Водных и экологических проблем СО РАН.

Cалтыков A.B., научный сотрудник лаборатории биогеохимии Института Водных и экологических проблем CO PAH.

Трошкова И.А., младший научный сотрудник лаборатории биогеохимии Института Водных и экологических проблем СО РАН.

Двуреченская С.Я., кандидат химических наук, ученый секретарь Новосибирского филиала Института Водных и экологических проблем СО РАН. 
UDC 556:556.314:550.47

\section{INFLUENCE OF THE BIOGEOCHEMICAL SITUATION OF THE LAKE TELETSKOE CATCHMENT (NORTH-EASTERN ALTAI) ON THE CONTENT OF THE MAJOR IONS AND Fe IN THE TRIBUTARIES WATERS}

\author{
Alexander V. Puzanov ${ }^{1}$, \\ puzanov@iwep.ru
}

Svetlana V. Baboshkina1, svetlana@iwep.ru, arsenida@rambler.ru Tamara A. Rozhdestvenskaya ${ }^{1}$,
rtamara@iwep.ru

\author{
Sergey N. Balykin 1 , \\ balykins@rambler.ru \\ 1 Institute of Water and Environmental Problems SB RAS, \\ 1, Molodezhnaya street, Barnaul, 656038, Russia. \\ 2 Institute of Water and Environmental Problems SB RAS, \\ 2, Morskoy avenue, Novosibirsk, Russia.
}

\author{
Dmitry N. Balykin 1 , \\ balykindn@yandex.ru
}

\author{
Alexey V. Saltykov ${ }^{1}$, \\ saltykov@iwep.ru \\ Irina A. Troshkova ${ }^{1}$, \\ egorka_iren@mail.ru
Serafima Ya. Dvurechenskaya², serafima_dv@mail.ru

The relevance of the research is caused by the necessity to expand and deepen knowledge about the formation and functioning of large freshwater objects, the chemical composition of which is closely related to the peculiarities of biogeochemical processes and soil cover of the catchment, with type of the anthropogenic environmental impact of catchment basins. However, the mechanisms of these interactions in the mountainous territories have not been fully studied yet.

The main aim of the research is to establish the relationship between the content of the major components in the tributaries waters of Lake Teletskoe and the features of their chemical denudation with the biogeochemical situation on the catchments.

Methods. Water samples from the tributaries of Lake Teletskoe were collected in clean polyethylene dishes in the estuary of the rivers, during the spring-summer high water and autumn low water. Determination of the ionic composition of surface waters $\left(\mathrm{HCO}_{3}{ }^{-}, \mathrm{Cl}^{-}, \mathrm{SO}_{4}{ }^{2-}\right.$, $\mathrm{Ca}^{2+}, \mathrm{Mg}^{2+} \mathrm{Na}^{+}$and $\mathrm{K}^{+}$) was carried out according to standard methods, with titrimetric or spectrophotometric completion. $\mathrm{Na}^{+}$and $\mathrm{K}^{+}$in 2018 and 2019 were determined by atomic emission spectrometry on the IRIS Advantage Thermo Jarrell Ash Corp. instrument. (1999). Fe content in waters and water extracts from soils was determined by atomic absorption spectrometry using electrothermal atomization on the SOLAAR M-6 device.

Results. It is established that the waters of the Lake Teletskoe tributaries are characterized by a low total mineralization (TDS), from 18 to $159 \mathrm{mg} / \mathrm{L}$. It is shown that the seasonal dynamics of the major ions is determined by the biogeochemical processes in the catchment. It is revealed that the waters of the eastern and western tributaries, draining different geological and landscape structures, as well as the degree of recreational load of the coast, differ both in content and in the ratio of the major ions. Thus, $\mathrm{Cl}^{-}$and $\mathrm{SO}_{4}{ }^{2-}, \mathrm{K}^{+}$and $\mathrm{Na}^{+}$make a greater contribution to the ionic composition of the waters of the eastern tributaries originating on the Korbu granite ridge, whereas in the waters of the western tributaries, draining sedimentary deposits for the most part, bicarbonates and calcium dominate. The influence of biogeochemical conditions of catchment on the content and ratio of iron in water and water extraction of soils is shown. It is revealed that most of the tributaries carry bicarbonate-magnesium-calcium type waters. The indicators of ion runoff of three tributaries of the lake of different sizes are calculated, chemical denudation in their catchment basins is estimated. In one year, 364 thousand tons of soluble salts enter the lake with the waters of the largest tributary - the Chulyshman River. 21 tons of salts are removed from $1 \mathrm{~km}^{2}$ of the Chulyshman River catchment (this is less than from the catchments of smaller tributaries), of which 12,8 tons are hydrocarbonates, 1,4 tons are chlorides, 1,6 tons are sulfates, 4,5 tons are calcium, 0,4 tons are magnesium.

\section{Key words:}

Lake Teletskoe, tributaries, catchment area, major ions, iron, biogeochemical situation, ion runoff.

The work was carried out within the framework of the state task of the IWEP SB RAS under project No. 0306-2021-0003 (state registration No. 1021032424138-9).

\section{REFERENCES}

1. Vernadskiy V.I. Biosfera i noosfera. [Biosphere and noosphere]. Moscow, Ajris-press Publ., 2012. 576 p.

2. Dobrovolskiy V.V. Osnovy biogeokhimii [Fundamentals of biogeochemistry]. Moscow, Vysshaya Shkola Publ., 1998. 413 p.

3. Bishop K., Seibert J., Köhler S., Laudon H. Resolving the double paradox of rapidly mobilized old water with highly variable responses in runoff chemistry. Hydrological Processes, 2004, vol. 18, pp. 185-189.
4. Stutter M.I., Deeks L.K., Low D., Billett M.F. Impact of soil and groundwater heterogeneity on surface water chemistry in an upland catchment. Journal of Hydrology, 2006, vol. 318, pp. 103-120.

5. Siwek J.P, Zelazny M., Chelmicki W. Influence of catchment characteristics and flood type on relationship between streamwater chemistry and streamflow: case study from Carpathian Foothills in Poland. Water Air and Soil Pollution, 2011, vol. 214. pp. 547-563.

6. Danilenko A.O., Reshetnyak O.S., Kosmenko L.S., Kondakova M.Yu. Changes in the chemical denudation intensity in the river Pechora catchment under the influence of non-stationary climate and eco- 
nomic activities. Water and ecology, 2020, vol. 84, no. 4, pp. 38-49. In Rus.

7. Taboada-Castro M.M., Rodriguez-Blanco M.L., Taboada-Castro M.T. Assessing the influence of catchment land-use patterns on the nutrients and major ions chemistry of drainage water. Communications in Soil Science and Plant Analysis, 2013, vol. 44, Iss. 1-4, pp. 422-428.

8. Chetelat B., Liu C.Q., Zhao Z.Q., Wang Q.L., Li S.L., Li J., Wang B.L. Geochemistry of the dissolved load of the Changiiang Basin Rivers: anthropogenic impacts and chemical weathering. Geochimica et Cosmochimica Acta, 2008, vol. 72 (17), pp. 4254-4277.

9. Zhang L., Song X.F., Xia J., Yuan R.Q., Zhang Y.Y., Liu X., Han D.M. Major element chemistry of the Huai River Basin, China. Applied Geochemistry, 2011, vol. 26, Iss. 3, pp. 293-300.

10. Musolff A., Schmidt C., Selle B., Fleckenstein J.H. Catchment controls on solute export. Advances in water resources, 2015, vol. 86, pp. 133-146.

11. Abduyev M.A.O. Chemical denudation on the Azerbaijan mountain territory. Water sector of Russia: problems, technologies, management, 2016, no. 1, pp. 4-16. In Rus.

12. Selegey V.V., Selegey T.S. Teletskoe ozero [Teletskoe lake]. Leningrad, Gidrometeoizdat Publ., 1978. 142 p.

13. Marinin A.M., Samoylova G.S. Fizicheskaya geografiya Gornogo Altaya [Physical geography of the Altai Mountains]. Barnaul, BGPI Publ., 1987. $110 \mathrm{p}$.

14. Avtomatizirovannaya informatsionnaya sistema gosudarstvennogo monitoring vodnykh obyektov [Automated information system for state monitoring of water bodies]. Available at: https://gmvo.skniivh.ru (accessed 20 June 2021).

15. Chernyh D.V., Samoylova G.S. Landshafty Altaya (Respublika Altay $i$ Altaysky kray) Masshtab 1:500000 [Landscapes of Altay (Republic of Altay and Altay Kray). Scale 1:500000]. Novosibirsk, Novosibirskaya kartograficheskaya fabrika Publ., 2011.

16. Novikov Yu.V., Lastochkina K.O., Boldina Z.N. Metody issledovaniya kachestva vody vodoemov [Methods of water quality research in reservoirs]. Moscow, Meditsina Publ., 1990. 397 p.

17. Lakin G.F. Biometriya [Biometrics]. Moscow, Vysshaya shkola Publ., 1990. $351 \mathrm{p}$.

18. Puzanov A.V., Baboshkina S.V., Dvurechenskaya S.Ya., Rozhdestvenskaya T.A. Impact of the biogeochemical situation at catchments on the microelement composition of lake Teletskoye tributaries' waters. Water and ecology, 2020, no. 3 (83), pp. 70-78 In Rus.
19. Efimova L.E., Povalishnikova E.S., Frolova N.L. Hydroecological features of the Multa river basin (Gorny Altai). Geography and natural resources, 2011, no. 1, pp. 34-42. In Rus.

20. Novikov D.A, Maksimova A.A., Napreev D.V., Kopylova Yu.G., Khvacshevskaya A.A. Geochemical features of natural waters in the basin of the Vitim river (Western regions of Patom upland). Bulletin of the Tomsk Polytechnic University. Geo Assets Engineering, 2021, vol. 332, no. 11, pp. 7-17. In Rus.

21. Savichev O.G., Domarenko V.A., Arbuzov S.I., Pshenichkin A.Ya., Wilgelm E.A. Ablation and accumulation condition of chemical elements in the mountain-glacial basin Aktru (Mountain Altay). Prospect and protection of mineral resources, 2019, no. 3, pp. 55-62. In Rus.

22. Dolmatova L.A. The peculiarities of hydrochemical regime of lake Teletskoye during its autumn cooling. World of Science, Culture, Education, 2011, vol. 6, no. 31, pp. 417-423. In Rus.

23. Maloletko A.M., Shestakova T.P. Materialy $k$ gidrokhimii basseyna Teletskogo ozera [Materials for the hydrochemistry of the Teletskoe Lake basin]. Voprosy geografii Sibiri [Questions of the geography of Siberia]. Tomsk, TGU Publ., 1979. pp. 110-126.

24. Khazheeva Z.I., Tulokhonov A.K., Dashibalova L.T. Seasonal and spatial dynamics of TDS and major ions in the Selenga river. $\mathrm{Wa}$ ter Resources, 2007, vol. 34, no. 4, pp. 444-449.

25. Hofmann H., Cartwright I., Morgenstern U. Estimating retention potential of headwater catchment using Tritium time series. Journal of Hydrology, 2018, vol. 561, pp. 557-572.

26. Cartwright I. Concentration vs. streamflow (C-Q) relationships of major ions in south-eastern Australian rivers: sources and fluxes of inorganic ions and nutrients. Applied Geochemistry, 2020, vol. 120, no. 104680 , pp. $1-11$.

27. Holloway J.M., Dahlgren R.A. Seasonal and event-scale variations in solute chemistry for four Sierra Nevada catchments. Journal of Hydrology, 2001, vol. 250, pp. 106-121.

28. Galaziy G.I. Baykal v voprosakh i otvetakh [Baikal in questions and answers]. Irkutsk, Vostochno-Sibirskoe knizhnoe izdatelstvo Publ., 1987. $167 \mathrm{p}$

29. Savichev O.G. Ion runoff of the Middle $\mathrm{Ob}$ and its major tributaries. Bulletin of the Tomsk Polytechnic University, 2004, vol. 307, no. 6, pp. 40-44. In Rus.

Received: 2 July 2021.

\section{Information about the authors}

Alexander V. Puzanov, Dr. Sc., professor, director, Institute of Water and Environmental Problems SB RAS.

Svetlana V. Baboshkina, Cand. Sc., senior researcher, Institute of Water and Environmental Problems SB RAS.

Tamara A. Rozhdestvenskaya, Cand. Sc., senior researcher, Institute of Water and Environmental Problems SB RAS.

Sergey N. Balykin, Cand. Sc., senior researcher, Institute of Water and Environmental Problems SB RAS.

Dmitry N. Balykin, Cand. Sc, scientific researcher, Institute of Water and Environmental Problems SB RAS.

Alexey V. Saltykov, researcher, Institute of Water and Environmental Problems SB RAS.

Irina A. Troshkova, junior researcher, Institute of Water and Environmental Problems SB RAS.

Serafima Ya. Dvurechenskaya, Cand. Sc., senior researcher, scientific secretary, Institute of Water and Environmental Problems SB RAS (Novosibirsk Department). 